\title{
MAPPAJA' PRACTICES IN AGRICULTURAL COMMODITY TRADING IN THE DISTRICT OF WEST SINJAI, SINJAI REGENCY
}

\author{
Ermiati $^{1}$ \\ Abdul Wahab ${ }^{2}$ \\ Abdul Wahid Haddade ${ }^{3}$ \\ Postgraduate Alumni of Sharia Economics, UIN Alauddin Makassar ${ }^{1}$ \\ Lecturer of the Faculty of Economics and Business, UIN Alauddin Makassar ${ }^{2}$ \\ Lecturer of the Faculty of Sharia and Law, UIN Alauddin Makassar ${ }^{3}$ \\ ermiatiabdullah3@gmail.com¹, abdulwahab210472@gmail.com² \\ ibnuhaddade@gmail.com ${ }^{3}$
}

\begin{abstract}
This study will elaborate on the form of mappaja' trading, which is considered as an attractive economic issue as in its transactions, people do not use a system of weighing scales in trading their harvests, but with a cost estimation system for the goods. Therefore, in the trading practice, there is often a discrepancy between the harvest and the buyer's expectation, because it may contain an element of gharar/obscurity of the goods, which can lead to an invalid transaction and harm one of the parties. This study indicated that the practice of mappaja' for agricultural commodities has occurred for a long time. The mechanism is by estimating the number of plants based on mutual trust and responsibility. The agricultural commodities used as the mappaja' objects are cloves and vegetables (carrots, cabbage, and tomatoes). The payment method in mappaja' practice is carried out in two ways, namely full payment and twice payment. Twice payment refers to the transaction where half of the payment was handed over on the agreement as a down payment and a sign of completion, then the rest of the payment were handed after the harvest. The condition of the plant is ready to harvest or not ready for harvest in the transaction of mappaja'. The rights and obligations of both parties are that traders are obliged to make payments to farmers according to the agreement and for the farmers, they have to keep taking good care of the plants if at the time of the transaction the condition of the plants is still not ready for harvest.
\end{abstract}

Keywords: Mappaja' Practices; Agricultural Commodities Trading

\section{BACKGROUND}

Trading is one form of mu'amalah; it refers to the relationship that occurs between humans. The form of mu'amalah named trading exists because it is based on a sense of mutual need. In this case, the seller requires the buyer to buy the goods in order to get money. Meanwhile, the buyer arranges the trading to get the goods needed.

Trading is a transaction carried out by the Prophet during his life; he taught trading based on likes and dislikes according to the legal terms and conditions. In everyday life, some people cannot own the things they need in their lives, the things they sometimes need in the hands of others, thereupon the trading is needed. In this case, people usually help each other in fulfilling the needs of life.

Trading is proof that humans are social creatures; it stands for the creatures that need other creatures to survive. Without trading, humans cannot fulfill their own needs; trading is an activity carried out in human life to maintain their lives in society. 


\section{Mappaja' Practices in Agricultural Commodity Trading in The District of West Sinjai, Sinjai Regency}

Trading as a medium of helping fellow human beings, in Islam, trading has a legal basis from the Qur'an, Hadith, and Ijma'. The law of trading is halal or permitted; every Muslim making a living can arrange the trading. The law of trading can become mandatory if trading is the only way people can maintain their lives.

In the implementation of trading, aside from having a seller and buyer, the process should also comply with the terms and conditions of trading, and the most important thing is that there is no element of deception and must be mutually agreeable or mutually pleased. There are four kinds of conditions in trading: the conditions for the occurrence of the contract (in'iqod), the conditions for the validity of the contract, the conditions for the implementation of the contract (nafadz), and the conditions for luzum. In general, the purpose of all these conditions is to avoid conflict between humans. ${ }^{1}$

In the sharia of commerce, Islam teaches that commerce will always be built the clarity. The clarity in the price, objects, and contract. Islam also stipulates to keep the commercial contracts dissociated from all chancy things, or what in Arabic it called gharar, which does not rule out the possibility of causing the falsehood. Trading in gharar will indirectly cause the economy of a country to become challenging to develop. $^{2}$

Most economic practices (especially trading) are based on hereditary customs and habits that tend not to view Islamic values or ethics. As Muslims, it is necessary to carefully understand the ethics of trading in Islam because the realm of trading is the land that can bring blessings. Therefore, trading should be carried out according to the perspective of fiqh, an Islamic science that examines the law and ethics of mu'amalah (transactions). This matter will lead us to figure out the boundaries of Islam that Muslims must carry out.

Trading in Islam must be complete with the pillars trading to be used as legitimate trading, and then there must be a seller, a buyer, an agreement, and the traded goods. ${ }^{3}$ Then the terms of the traded goods must be evident, and there are four conditions for the traded goods; namely, the traded goods must exist, the traded goods must be valuable, the goods must be owned by themselves, and the goods to be sold can be handed over at the time of transaction. ${ }^{4}$

The development of the types and forms of mu'amalah carried out by humans since then until now continues to develop in line with the development of human needs and knowledge in fulfilling their individual needs. ${ }^{5}$ Humans develop science and technology according to the development of the current era so that the problems of trading that occur in society are getting wider.

Related with the trading, which is evidence of a sense of mutual need, where the seller needs money from the buyer (trader) and vice versa, the buyer (trader) also needs

\footnotetext{
${ }^{1}$ Parmadi, "Tinjauan Hukum Islam Terhadap Praktek Jual-Beli Hasil Pertanian Secara Tebas", Naskah Publikasi (Surakarta: Fak. Agama Islam Universitas Muhammadiyah Surakarta, 2014). p.2.

${ }^{2}$ Purbayu Budi Santosa dan Aris Anwaril Muttaqin, “Larangan Jual Beli Gharar: Tela'ah terhadap hadis dariMusnad ahmad bin hanbal”, Equilibrium 3, no. 1 (2015): p. 156

${ }^{3}$ Wardani, Fiqh Ekonomi Syari'ah: Fiqh Muamalah (Jakarta: PT Kencana Perdana Media 2013), p. 102

${ }^{4}$ Wardani, Fiqh Ekonomi Syari'ah: Fiqp...., p. 102

${ }^{5}$ Nazar bakri, Problematika Pelaksanaan Fiqh Islam (Jakarta: PT Raja Grafindo persada, 1994), p. 58.
} 
goods from the seller. Based on this explanation, if we look at the division of maslahah, namely: Al-dharuriat (immediate needs), al-hajiyat (secondary needs), and altahsiniyat/al-kamaliyat (tertiary needs), then trading is classified as maslahah in terms of al-hajiyat (secondary needs).

The aims of maslahah in terms of al-hajiyat (secondary needs), such as (1) enforcement of justice and equality in society, (2) increasing social security, mutual assistance, and solidarity, significantly to help the poor and needy in fulfilling their basic needs, (3) keeping the peace and security, (4) the enhancement of cooperation in terms of goodness and the prohibition of the misconduct, and (5) the enhancement of the maximum universal moral values and all actions that are necessary for the preservation and mastery of nature.

Unfortunately, according to the researchers, there are still many things done that are not under Islamic law in the practice of trading. They only care about the worldly benefits they get without considering the impact of trading practices. As happened in society, especially in the community of West Sinjai District, Sinjai Regency. In this area, the practice of trading with the mappaja' system has been found.

Mappaja' is a trading transaction of plantation commodities when the plants are not ready to be harvested. There are two plantation commodities in this study: long-term crops such as cloves, and short-term crops such as vegetables. For clove plants, the transaction is carried out when the fruit is still on the tree in a condition that is not ready for picking. The vegetables such as potatoes, cabbage, carrots are still in the same condition, which is not yet feasible or not ready for harvest.

The term of mappaja' in Indonesia is generally known as ijon. The definition of ijon in the Indonesian dictionary is the purchase of rice before it is cooked and taken by the buyer after it is cooked; or credit granted to farmers, fishers, or small entrepreneurs where the payment is done with the harvest or production based on the low selling price. ${ }^{6}$ Whereas in fiqhi literature, it is known as mukhadarah, it is the trading of fruits that are still on the tree and have not ready for picking.

The term mappaja' also occurs in other regions but it uses a different term. The other terms of mappaja', namely: (1) Wholesale trading (i.e., when the plants have not been picked, the plants to be purchased are still alive), ${ }^{7}$ also interpreted as (trading using an estimation system). ${ }^{8}$ (2) Ijon (that is, an agreement made to obtain future results from objects with uncertain results), ${ }^{9}$ other studies also interpret bond as (trading cloves that are still on the tree), (3) Tebasan (estimation system or in Islam it can be matched with al-Juzāf trading, it refers to a prediction or estimation system $^{10}$.

${ }^{6}$ http://www.kbbi.web.id.

${ }^{7} J u n i$ Iswanto, "Pelaksanaan Jual Beli Hasil Pertanian Dengan Cara Borongan Ditinjau Dari Fiqih Muamalah Didesa Mancon Kecamatan Wilangan Kabupaten Nganjuk", Jurnal Dinamika Ekonomi Syariah 6, no. 2 (2019): p.148.

${ }^{8}$ Juju Jumena, dkk., “Jual Beli Borongan Bawang Merah di Desa Grinting Menurut Tinjauan Hukum Islam”, Al-Mustashfa 2, no. 2 (2017): p. 152.

${ }^{9}$ Abdul Haris, "perjanjian jual beli duku dengan sistem ijon antara pembeli dengan masyarakat kecamatan maro sebo kabupaten muara jambi", Jurnal Ilmiah Universitas Batanghari Jambi 13, no. 4 (2013): p. 36.

${ }^{10}$ Azizatul Mahmudah dan Bakhrul Huda, "Praktik Jual Beli Jagung dengan Sistem Tebasan di Desa Triwung Lor Kecamatan Kademangan Kota Probolinggo Perspektif Akad Juzāf", el-Qist: Journal of Islamic Economics and Business 10, no. 2 (2020): p. 122. 


\section{Mappaja' Practices in Agricultural Commodity Trading in The District of West Sinjai, Sinjai Regency}

The problem of mappaja' trading (ijon) becomes contradictory among the Fuqaha, considering that there are many problems in the trading of ijon, both from the expansion of existing laws and the existence of ijon in other forms. Ijon trading is commonly found in rural communities, and this practice usually occurs in fruits trading. ${ }^{11}$

This study will elaborate the form of mappaja' trading, which is considered as an attractive economic issue as in its transactions, people do not use a system of weighing scales in trading their harvests, but with a cost estimation system for the goods. Therefore, in the trading practice, there is often a discrepancy between the harvest and the buyer's expectation because it may contain an element of gharar/obscurity of the goods, which can lead to an invalid transaction and harm one of them the parties.

\section{LITERATURE REVIEW}

This study focuses on the overview of the maslahah of mappaja' practices in the trading of agricultural commodities in West Sinjai by developing the new skills and approaches and solving a problem by directly applying them to a particular environment in the natural setting. Previous studies are used as the material for comparison with the study conducted by researchers, for finding out the comparison and relation to this study, here are some scientific works, such as:

Juni Iswanto in his study aims to find out the implementation of the trading of the agricultural products by occurring wholesale in terms of Fiqh Mu'amalap. His study explaines that (a) Selling agricultural products by wholesale is the choice for farmers because it has fewer of risks. For instance, the farmers will get the profits early rather than waiting until the harvest time come in which the money they got from the current harvest can be used for other needs. In addition, with this wholesale method, farmers do not need to find any labor for the harvest process. (b) In terms of Fiqh Mu'amalah it is allowed to be done because it follows the rules of Islamic law, with the sellers' and buyers' willing, and there will be no disputes in the future. ${ }^{12}$

Siti Khaizul Mustaqimah, in her study concluded that (a) The practice of trading uses several types of trading, namely tebasan trading that is carried out when the durian fruit has has not bloomed or just bloomed, the tebasan trading which is done when the durian fruit has seen well, or it is about five months old and trading in the way of contracts/renting the durian trees to pick the fruit only in a few seasons. (b) The implementation of the trading practices in the durian trees in terms of the view of the Fathu al-Qarīb book, there are two valid and invalid classifications. The trading of durians which is done in tebasan way when durian has not been seen well is indicated as invalid trading because even though the pillars are fulfilled, there are conditions for trading that are not fulfilled. It is in terms of the object (ma'qüd 'alaih) which contains the elements of garar, where the estimated results of the doer of tebasan are not uncertainly under the harvest and can inflict one of the parties. In contrast, the trading of tebasan done when the durian has seen well, which is about five months old, is

\footnotetext{
${ }^{11}$ Nazar bakri, Problematika Pelaksanaan.... p. 58

${ }^{12}$ Juni Iswanto, "Pelaksanaan Jual Beli Hasil Pertanian Dengan Cara Borongan Ditinjau Dari Fiqih Muamalah Didesa Mancon Kecamatan Wilangan Kabupaten Nganjuk”, p. 146.
} 
indicated as valid because it does not cause an element of garar and has complied with the pillars and terms of the trading. ${ }^{13}$

Abdul Haris, in his study, concluded that the implementation of the ijon trading agreement of duku fruit between the buyer and the community (the seller) in the Maro Sebo district, Muaro Jambi regency, in general, was not following with the agreement they mutually agreed. It was contrary to the applicable laws and regulations because some people do default, and there are also many obstacles from this practice, such as damage to the traded goods. ${ }^{14}$

Azizatul Maheasy and Bakhrul Huda. This study used a phenomenological approach with fiqh analysis tools named juzaf contracts. The resulting study reveals that the practice of corn trading with tebasan system by the Muslim community in Triwung Lor, Kademangan district, Probolinggo City tended to have fulfilled the juzāf trading contract, which refers to the trading allowed plurally by the fiqh clerics for the objects that cause mashaqqah (difficulties) and has become a necessity for the majority of people because of the convenience in undertaking it. ${ }^{15}$

Syamsuddin A. K Antuli, in his study, tried to see how the community understands the implementation of the practice of trading the cloves that are still on the tree. His study found that the understanding of the community, especially the clove farmers, about Ijon trading was very diverse. Some even did not understand it at all. This diversity follows the results of the researchers' observation because the lack of religious knowledge influences it. Information about ijon's problem is based on the results of the question-and-answer observations; the community's average does not know and cannot even answer the question. ${ }^{16}$

Juju Jumena, et al. This study examines the wholesale trading of onions with a review of Islamic law. From the results of this study, it was found that there are two forms of trading the onions in Grinting village, namely scale (small-scale Rogolan and Gedengan at the souvenir shop) and wholesale (large-scale rogolan, gedengan, larikan, and tebasan). According to the review of Islamic law, wholesale trading is carried out based on the conditions of jizaf, so that if it fulfills the conditions of jizaf trading, the trading is legal or permitted. ${ }^{17}$

Maryani, et al. This study aims to determine the implementation of ijon trading in Segaran Village, Tiris District, Probolinggo Regency according to the views of the Imam Syafi'i madhhab and the supporting factors and obstacles to the implementation of ijon trading in Segaran Village, Tiris District, Probolinggo Regency. The results of this study show that the law of this ijon trading transaction that occurs in Segaran Village,

\footnotetext{
${ }^{13}$ Siti Khaizul Mustaqimah, "Praktik Jual Beli Durian Secara Tebasan Dalam Kajian Kitab Fathu Al-Qarīb: (Studi Kasus di Desa Mantenan Giyanti Kecamatan Candimulyo Kabupaten Magelang)", Wahana Islamika: Jurnal Studi Keislaman 6, no. 1, 2020 p. 64.

${ }^{14}$ Abdul Haris, "Perjanjian Jual Beli Duku Dengan System Ijon Antara Pembeli Dengan Masyarakat Di Kecamatan Maro Sebo Kabupaten Muaro Jambi”, p. 39.

${ }^{15}$ Azizatul Mahmudah dan Bakhrul Huda, "Praktik Jual Beli Jagung dengan Sistem Tebasan di Desa Triwung Lor Kecamatan Kademangan Kota Probolinggo Perspektif Akad Juzāf”, p. 120.

${ }^{16}$ Syamsuddin A. K Antuli, "Pemahaman Masyarakat Tentang Jual Beli Cengkeh Yang Masih Di Pohon (Ijon) Di Kecamatan Passi Barat Kabupaten Bolaang Mongondow", Journal Economic and Business of Islam 2, No. 1, Juni 2017 p. 2.

${ }^{17}$ Juju Jumena, dkk., "Jual Beli Borongan Bawang Merah di Desa Grinting Menurut Tinjauan Hukum Islam", p. 152.
} 


\section{Mappaja' Practices in Agricultural Commodity Trading in The District of West Sinjai, Sinjai Regency}

Tiris District, Probolinggo Regency is forbidden according to the view of the Imam Syafi'i madhhab. While the factors that are supporting the implementation of the trading of ijon (fruit) in Segaran Village are three factors: the sudden need factor, the education cost factor, the situation and condition factors such as hospital costs, and vehicle reparation and wild animals. Two factors become the resistor for implementing of the ijon trading (fruit) in Segaran Village, such as the difficult location and the damaged fruit. $^{18}$

Abdul Kholiq Syafa'at and Rohmatullap. His study aimed to determine the practice of agricultural products trading with tebasan system in Kelir Hamlet, Bunder Village, Kabat District, Banyuwangi Regency. Besides, to find out the review of Islamic law on the practice of trading, the result of this study is the practice of the trading: firstly, the seller will offer rice to the buyer, then the buyer will come to survey and estimate the price of the rice, after being surveyed, the bargaining will be conducted to reach an agreement with the farmer, after that the one counduct tebasan gives the down payment (debt) as a sign of completion and the rest is paid off when the rice is harvested. The provisions of Islamic law on the practice of trading with tebasan system in Kelir Hamlet, Bunder Village, Kabat District, Banyuwangi Regency concluded that the trading practice which carried out was legal because it was following the terms of the jizaf trading and had fulfilled the pillars and conditions of the jizaf trading itself. ${ }^{19}$

Nurul Inayah, in her study, aims to analyze the Islamic law on the practice of melons trading with tebasan system. The results of her study are: (1) the implementation of the practice of melons trading with tebasan system is allowed. The terms and pillars of trading have been fulfilled, (2) the provisions of Islamic law on the practice of melons trading with tebasan system carried out are legal because they are following the provisions of Islamic law, where the terms and pillars of trading are fulfilled. On the other hand, trading with tebasan system also includes various types or models of trading transactions named jizaf trading. Jizaf trading refers to trading transactions with a prediction or forecast system. It means that the trading of commodities that own the method of knowing the level is using size (dzar" $i)$, scales (wazn), or measure (hook), but it is sufficed by relying on the takhim (prediction) method after testifying it. ${ }^{20}$

\section{RESEARCH METHODOLOGY}

This study is field research which is classified as a qualitative descriptive using a phenomenological approacp. Methods of data collection through observation, documentation, and interviews.

\footnotetext{
${ }^{18}$ Maryani, dkk., "Pelaksanaan Jual Beli Ijon Di Desa Segaran Kecamatan Tiris Kabupaten Probolinggo Menurut Madzhab Imam Syafi'I”, p. 121.

${ }^{19}$ Abdul Kholiq Syafa'at dan Rohmatullah “Analisis Hukum Islam Terhadap Praktik Jual Beli Hasil Pertanian Padi Sistem Tebasan Di Dusun Kelir Desa Bunder Kecamatan Kabat Kabupaten Banyuwangi", p. 162.

${ }^{20}$ Nurul Inayah, “Analisis Hukum Islam Terhadap Praktek Jual Beli Buah Melon Dengan Sistem Tebas: Studi Kasus di Desa Buluagung Kecamatan Siliragung Kabupaten Banyuwangi”, p 67.
} 


\section{IV.FINDINGS AND DISCUSSION}

\section{A. General Description of Mappaja'}

Mappaja' trading system is a transaction that has formerly occurred, and it is still ongoing today. Trading with the mappaja' system is considered normal and is commonly done by the community, especially in West Sinjai. Regarding the occurrence of mappaja' practices, especially in West Sinjai, Baharuddin, it is explained that:

"The community has been doing the practice of mappaja' for some time because it is considered to be more profitable. In fact, most people choose to sell their agricultural products by mappaja' rather than by kilo. "2l

Baharuddin's explanation was strengthened by Umar, who said that:

"I have worked as a trader for a very long time, and the practice of mappaja' on the plants has happened and it is still being carried out today. "22

Based on the explanation above, it is known that the practice of mappaja' for agricultural commodities has been held for a long time, and it is still being carried out by the community. In fact, the community is more dominant in making sales with mappaja' transactions because it is considered more profitable in several ways.

Two types of agricultural commodities are often used as mappaja' objects, namely long-term crops such as cloves and short-term crops such as vegetables (cabbage, carrots, and tomatoes). There are two types of crop conditions when they would be sold under the mappaja' system, namely: (1) the plants is ready to harvest, and (2) the plants are still not ready for harvest, which means they still have to wait about one or two months until it is ready to be harvested after the contract taken.

\section{B. The Subject and Object of Mappaja'}

As with the other transactions, trading also requires the existence of pillars and conditions as the enforcers. One of the pillars and conditions for the validity of trading in Islam is that there are people who have a contract and goods (ma'qud alaih). Without these pillars and conditions, trading is indicated as illegal. ${ }^{23}$ In this case, the parties who undertake the trading transactions with the mappaja' system are the people of West Sinjai districts who are sellers and buyers by choosing agricultural commodities as the objects. The agricultural commodities here referred to the vegetable crops such as (tomatoes, cabbage, and carrots) and plants such as cloves. As the statement from Umar, who has been a trader for a long time and also often buys with the mappaja' system related to the agricultural commodities that they often use as the objects in mappaja', namely:

"As long as I trade and practice mappaja', I often buy carrots and cabbages. The plants' condition is that some of them are ready to harvest, and the rest still has to be awaited for about one month before the harvest time."24

\footnotetext{
${ }^{21}$ Baharuddin (39 years old), , Interview, Sinjai, January $8^{\text {th }} 2021$.

${ }^{22}$ Umar (66 years old), Merchant, Interview, West Sinjai, January $8^{\text {th }} 2021$.

${ }^{23}$ Suhrawardi K. Lubis dan Farid Wajdi, hukum Ekonomi Islam (Jakarta: Sinar Grafika, 2012), p.

${ }^{24}$ Umar (66 years old), Merchant, Interview, West Sinjai, January $8^{\text {th }} 2021$
} 140. 


\section{Mappaja' Practices in Agricultural Commodity Trading in The District of West Sinjai, Sinjai Regency}

Akbar also gave a similar statement:

"The plants that I often sell using the mappaja' system are tomatoes and cabbage, and all of the plants are ready for harvest." 25

Apart from the types of plants, Winda also explained about the plants that she bought with the mappaja' system, namely:

"The plants that I have bought using mappaja' are cloves and the conditions are ready to harvest. "26

From some of the explanations above, we can see that the agricultural commodities often used as objects in mappaja' are vegetable crops, such as carrots, tomatoes, and cabbage. Besides, there are also other types of plants such as cloves. There are two kind of condition of the plants in the mappaja' transaction, such as the plants are in the condition of ready to harvest and also in a condition of not ready for harvest. If we look at the pillars and conditions of trading, this mappaja' practice has fulfilled the criteria. The seller and buyer should exist, and there are goods to trade.

\section{Table 4.8}

Object and the Plants' Condition at the Initial of the Contract

\begin{tabular}{|c|l|l|l|}
\hline No & Plants & Harvest time & \multicolumn{1}{|c|}{ The age of the plant at the contract } \\
\hline 1 & Carrots & Three months & $\begin{array}{l}\text { Ready to harvest in 3 months old. Sometimes } \\
\text { it is sold early in 2 months old, so the buyer } \\
\text { should wait one month for the harves. }\end{array}$ \\
\hline 2 & Cabbage & Three months & $\begin{array}{l}\text { Ready to harvest in 3 months old. Sometimes } \\
\text { it is sold early in 2 months old, so the buyer } \\
\text { should wait one month for the harves. }\end{array}$ \\
\hline 3 & Tomatoes & Three months & $\begin{array}{l}\text { Ready to harvest in 3 months old. Sometimes } \\
\text { it is sold early in 2 months old, so the buyer } \\
\text { should wait one month for the harves. }\end{array}$ \\
\hline 4 & Cloves & Three months & $\begin{array}{l}\text { Ready to harvest in 3 months old. Sometimes } \\
\text { it is sold early in 2 months old, so the buyer } \\
\text { should wait one month for the harves. }\end{array}$ \\
\hline
\end{tabular}

Source: Processed data, 2021

\section{Stages in The Mappaja' Transaction}

The stages in the mappaja' transaction are as follows:

1. Contacting the Traders and Farmers

When the plants are close to harvest time, or the fruit looks ripe, then the plant can sell by mappaja'. At this stage, the merchant will come to the farmers to buy their crops by mappaj $a^{\prime}$. In addition, some farmers come to merchant to offer their plants to be bought by mappaja' because they need money. As Akbar stated that:

\footnotetext{
${ }^{25}$ Nur Akbar (27 years old), Farmer, Interview, West Sinjai, January $8^{\text {th }} 2021$

${ }^{26}$ Winda (27 years old), Merchant, Interview, West Sinjai, January $8^{\text {th }} 2021$
} 
"Mappaja' begins when the traders come to the farmers to buy plants that are still in the land or have not been harvested. If the farmer agrees to sell it then the contract will be processed." 27

Apart from Akbar's explanation, Ali's interview also explained that:

"When I want to sell the plants by mappaja', I come to the merchant. After that, I will go to the location with the merchant to see the condition of the plants." 28

Based on the explanation above, it can be discovered that in the process of plants trade with mappaja' system, the merchant will come to the farmer or vice versa; the farmers will come to the merchant to offer their crops. But what oftenly happened is that the merchant will come to the farmers to buy their crops. If the farmer agrees, then both parties will go to the location to directly observe the condition of the plant. After that, the contract process could take place.

\section{Price Estimation Method}

Before the price determination stage occurs, the traders and farmers will first come to the location to see the quality and extent of the plants. After that, they are going to determine the price. The method used in determining the price is by estimating yield obtained after harvesting based on the samples acquired and the surface area, and the number of seeds sown. The broader and more seeds are sown, the higher price will be obtained. As Ali explained that:

"Talk about determining the price; it depends on the area and the current price (i.e,. at the transaction held). If the land is large, much money would be gained, but even though the land is a bit narrow but the price is reasonable, the estimated price would also be higp. In addition, it is also affected by the number of seeds sown." 29

Carrying out the practice of mappaja', requires mutual trust, responsibility, and sincerity. The party that determines the price is the merchant. Even so, both parties must continue to assess and then carry out the negotiation stage to get a price agreement. For more details, here are some illustrations related to the calculation method using an estimation system. Baharuddin explained that:

"Carrots, for instance, in one land, a farmer sows 1 liter of seeds, so the buyer takes the price benchmark from it. The calculation is based on a count per tonne then multiplied by the current price. For example, the current price is IDR $2,600 / \mathrm{kg} \times 1$ ton $=I D R 2,600,000$, then this price will be paid to the merchant if an agreement has been reached. So the more expansive the land is and the plentiful plants, the higher the estimated price. "30

Based on the explanation, the mechanism for estimating the price for carrots is based on the surface area and the number of seeds sown, which is then calculated in

\footnotetext{
${ }^{27}$ Nur Akbar (27 years old), Farmer, Interview, West Sinjai, January $8^{\text {th }} 2021$

${ }^{28}$ Ali.C (48 years old), Farmer, Interview, West Sinjai, January $8^{\text {th }} 2021$.

${ }^{29}$ Ali.C (48 years old), Farmer, Interview, West Sinjai, January $8^{\text {th }} 2021$.

${ }^{30}$ Baharuddin (39 years old), Gabled, Interview, Sinjai, January $8^{\text {th }} 2021$.
} 


\section{Mappaja' Practices in Agricultural Commodity Trading in The District of West Sinjai, Sinjai Regency}

tons. This number of estimation (tons) will be multiplied by the current price in the market

In addition, the results of other studies with different types of plants, namely tomato plants, explained by Akbar:

"The pricing mechanism depends on the type of plant as well as its area. For instance, in tomatoes, the merchant checks and estimates the number of plants in one land. For example, it is estimated that there are about 1000 trees in one land, with an estimate of one tree bearing about 2 kilograms at a price of about IDR 2000 per kilogram, so for one tree, it is charged (IDR. $4000 \times 1000$ trees $=$ IDR 4,000,000). So, this amount will then be negotiated by both parties. If the agreement is achieved, the plant has become the merchants' right; to take fruit and the merchant gives the money according to the agreed amount with the farmer, it can be paid at once, and it also can be paid twice, the rest will be paid after the harvest. " 31

Besides being affected by price, surface area and also the number of seeds sown, for tomato plants, the estimation method is based on the number of fruits of one tree which will then be multiplied by the estimated number of trees for one location, which merchant will pay to the farmers. Therefore, for each type of plant, there are some differences in terms of estimation.

Likewise with the type of clove plant, when the contract takes place, the plant is ready to harvest or still has to wait for one month to be harvested. Estimation method based on the samples obtained and estimates that for one tree it will bear several liters, and then it will be multiplied by the price prevailing in the market. So if we compare it with short-term crops such as vegetables, the mechanism for setting the price is nearly the same. It uses estimating method. However, it has some differences such as: (1) the estimation of carrot plants is based on the number of tons multiplied by the current price, (2) the estimation of the tomatoes is based on the number of fruits ( $\mathrm{kg}$ ) produced for one tree, then multiplied by the estimated number of trees for one location, (3) while the estimation of the clove plant is based on the estimated number of liters per tree.

The mechanism for estimating prices for clove plants is explained by Winda:

'I buy cloves with the mappaja' system when the harvest time comes; it is about one month after the contract. The way I set the price, first, I notice the clove fruit that is still on the tree, and then I estimate the number of results obtained after the harvest. For example, one tree is estimated to bear 100 liters of fruit, so as a trader, I will calculate how much I have to spend for the harvesting rent based on the current costs. For example, for harvest costs, we have to pay 3500/liter. So $(100$ liters $x I D R 3,500=I D R 350,000)$, this is the amount that must be spent for the cost of harvesting. So for example, if the estimated amount is 100 liters multiplied by the current price, for example, IDR 10,000/kg, the result is (100 liters $x$ IDR 10,000 = IDR 1,000,000) so, from the total cost, I subtract the rental fee $(I D R$ 1,000,000 - IDR). 350,000 =IDR 650,000). From this final total, I gave the price to the merchant for negotiation. So if the agreement is achieved, this is the amount of money that I have to give to the merchant, either full or

${ }^{31}$ Nur Akbar (27 years old), Farmer, Interview, West Sinjai, January $8^{\text {th }} 2021$ 
only in part; the rest could be given after harvest and it depends on the early discussion." 32

From some of these explanations, it can be seen that the pricing mechanism in trading transactions with the mappaja' system for both types of vegetables and other plants such as cloves is nearly the same. It uses an estimation system based on the surface area, the number of seeds sown, and the number of fruits or yields for one location.

\section{The Contract in Mappaja' Transactions}

Regarding the issue of mu'amalah, the contract or agreement is one of the essential points. In the contract, everything must be explained to avoid problems in the future. In general, the practice of mappaja' in West Sinjai is carried out when the plants have not been harvested or are still on the land with two kinds of conditions, namely: first, the plant is ready to harvest, and the second, the plant is still not ready for harvest (i.e., still have to wait until one or two months for harvest).

After both parties came to the location and saw the condition of the plants, they negotiated the price, the agreement was made related to the price, and then the contract prevailed. In this case, everything related to the mappaja' transaction must be explained in the contract, such as payment methods, the rights, and obligations of both parties.

\section{Payment Method}

There are two payment methods in mappaja' transactions; first, the farmer will receive the down payment as a sign of completion and the remainder after harvesting. Second, the farmer will receive full payment from the merchant. It depends on the discussion or agreement when the contract is taken as explained by Sumarni that:

"The payment process at mappaja' depends on the discussion. Sometimes the merchant pays the seller directly in total, and sometimes it is also paid twice; it is paid in half in the initial agreement, and the rest is paid after the harvest. "33

The response from Herliati strengthens the explanation above:

"About the payment, we usually receive the money in full immediately, but it is also customary to only get it in part, and the rest is handed over after harvest. Nevertheless, this issue depends on the discussion."

So, regarding the issue of payment, it depends on the agreement of both parties. i.e., to make a one-time payment or make it twice; it refers to the down payment as a sign of completion, and the rest is handed over after harvesting.

2. The method used in the contract

The practice of trading with the mappaja' system in the agricultural commodities in West Sinjai district conduct the process of the agreement or contract verbally based on the mutual trust and responsibility because there is no firm evidence of transactions such as an agreement that is written on the blank paper. Also, there are no witnesses in it. As stated by Baharuddin that:

\footnotetext{
${ }^{32}$ Winda (27 years old), Merchant, Interview, West Sinjai, January $8^{\text {th }} 2021$

${ }^{33}$ Sumarni (40 years old), Merchant, Interview, West Sinjai, January $8^{\text {th }} 2021$
} 


\section{Mappaja' Practices in Agricultural Commodity Trading in The District of West Sinjai, Sinjai Regency}

"The contract in mappaja' only uses an estimation system, and it is only based on mutual trust because there is no written evidence or witnesses when the contract is undertaken." 34

Other interview results from Sumarni who revealed the same thing with Baharuddin, related to the issue of the contract:

'In the mappaja' transaction, there are no witnesses or documents of evidence.

We only need mutual trust and responsibility. "35

From the statement above, it can be seen that in the practice of mappaja', the contract used is only verbally based on mutual trust and responsibility, and there is no written evidence or witnesses in it. In mappaja' practice, there should be strong evidence in written form, and there must also be witnesses in signing the contract so it can be used as a guide if any problems occur in the future. Moreover, mappaja' practice, commonly carried out by the community, the payment is made twice, i.e., half of the payment is paid when the contract is assigned, and the rest is paid after the harvest. This matter then requires strong evidence for both parties.

Regarding the responsibility, Islam has also explained it as stated in QS AlMuddatstsir/74: 38.

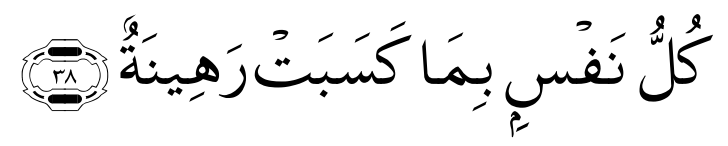

Meaning:

"Each person is responsible for what he/she has done. "36

This verse defines that each person is responsible for all the things that they have done. The charity of their deed can save them or lead them into the downfall.

Besides, it is also clearly commanded in Islam that in mu'amalah such as (trading, debts, or renting and so on) to note it if it is done cashless. As Allah says in QS Al-Baqarah 2: 282
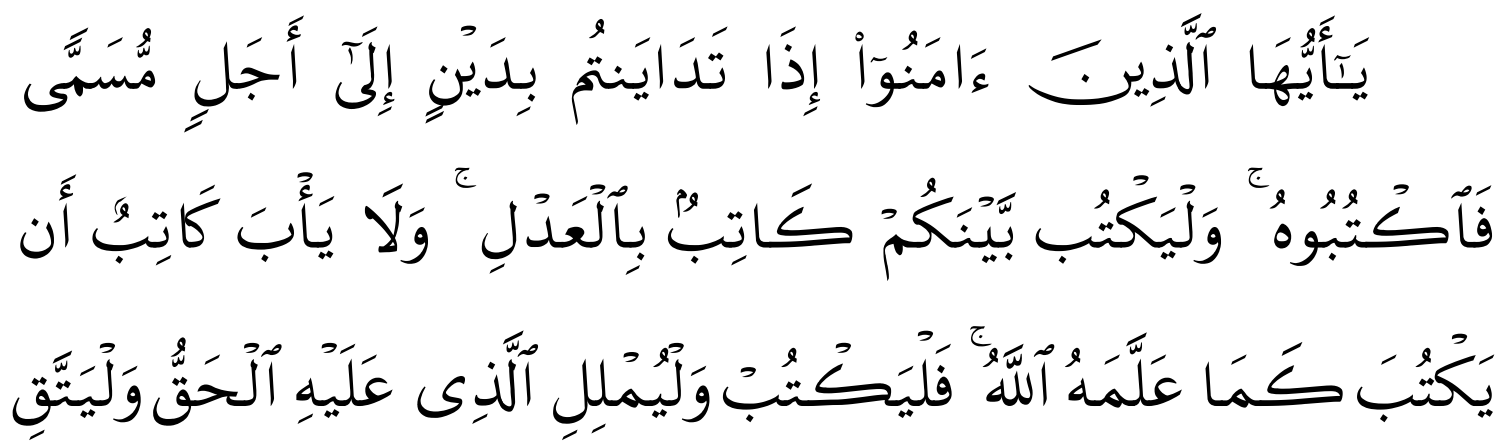

\footnotetext{
${ }^{34}$ Baharuddin (39 years old), Gabled, Interview, West Sinjai, January $8^{\text {th }} 2021$.

${ }^{35}$ Sumarni (40 years old), Merchant, Interview, West Sinjai, January $8^{\text {th }} 2021$.

${ }^{36}$ Departemen Agama RI, Al-Quran Dan Terjemahnya..., p.576
} 


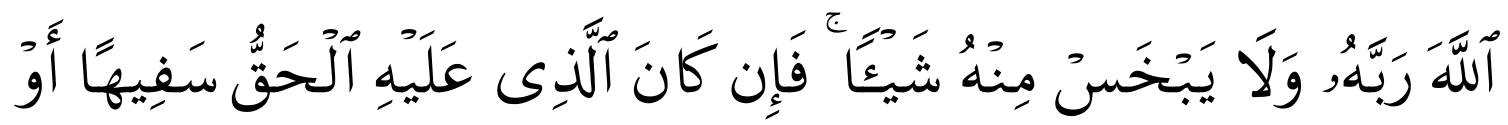

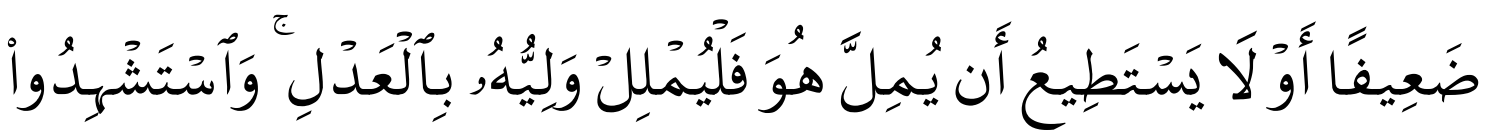

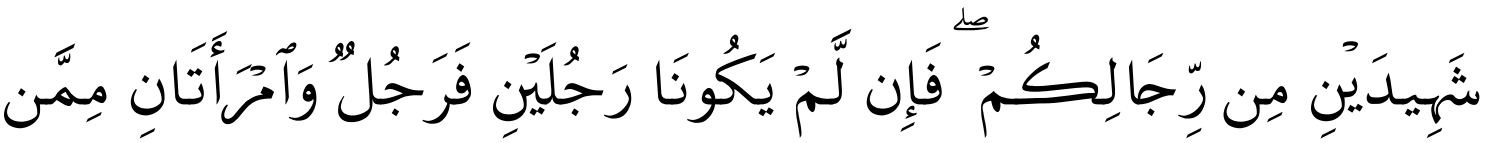

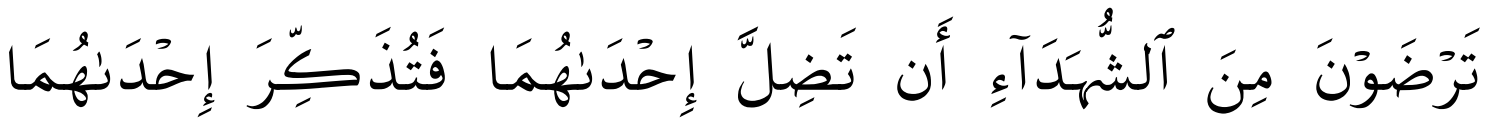

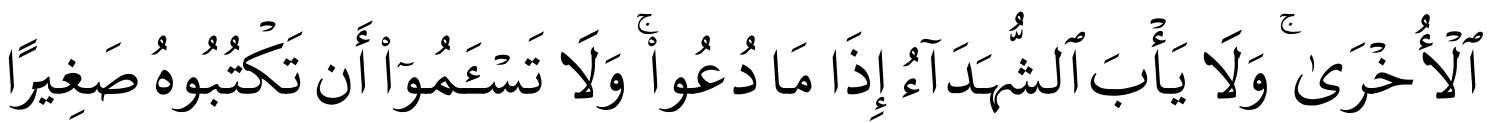

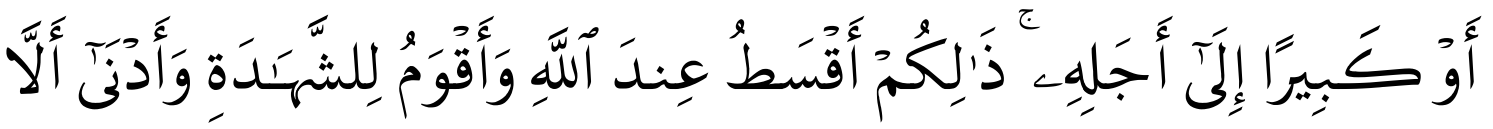

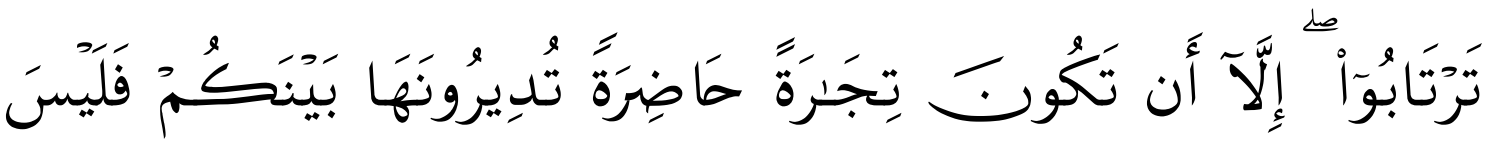

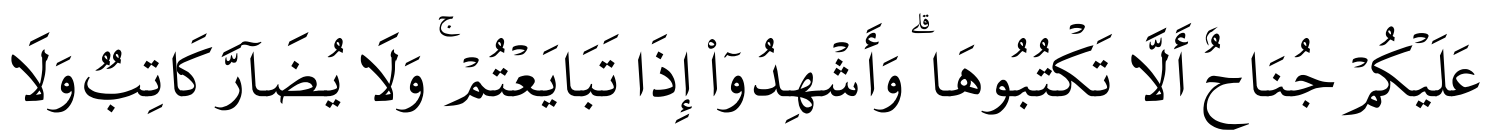

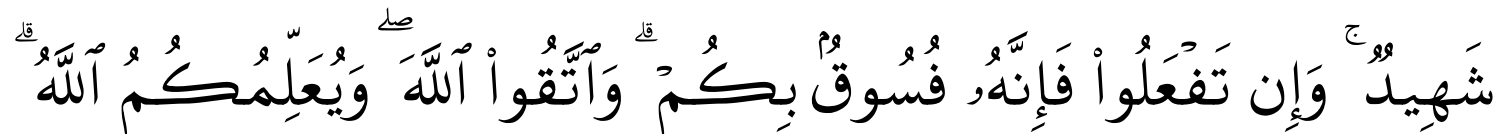

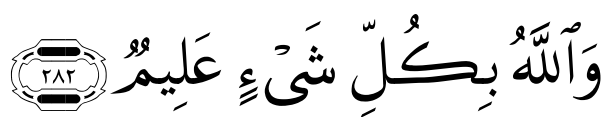

Meaning:

"O you who have believed, when you contract a debt for a specified term, and let a scribe write [it] between you injustice. Let no scribe refuse to write as Allah has taught him. So let him write and let the one who has the obligation [i.e., the debtor] dictates, and let him fear Allah, his Lord, and not leave anything out of it. But if the one who has the obligation is of limited understanding or weak or unable to dictate himself, then let his guardian dictate injustice, and bring to witness two witnesses from among your men. And if there are not two men [available], then a man and two women from those you accept as witnesses - so that if one of them [i.e., the women] errs, then the other can remind her, and let not the witnesses refuse when they are called upon, and do not be [too] weary of writing it, whether small or large, for its [specified] term. That is more just in the sight of Allah and stronger as evidence and more likely to prevent doubt between you, except when it is an immediate transaction which 


\section{Mappaja' Practices in Agricultural Commodity Trading in The District of West Sinjai, Sinjai Regency}

you conduct among yourselves. For [then] there is no blame upon you if you do not write it. And take witnesses when you conclude a contract. Let no scribe be harmed or any witness. For if you do so, indeed, it is [grave] disobedience in you. And fear Allap. And Allah teaches you. And Allah knows of all things. "37

The meaning of the verse above is an order for people who believe in Allah to keep a record of transactions made in cash or debts, where some of you are lending to others with a specific time limit, then let it be adequately recorded. Besides, two male witnesses or one male and two female witnesses should be used. Unless the transaction is in cash, then there is no problem if you do not record it.

3. The rights and obligations of both parties

In the process of making the contract/agreement in the mappaja' transaction, limits for the merchant to harvest all crops must be explained and agreed. Do not let the price decreased on the harvest time so that the merchant does not harvest the plants quickly while it has to be plowed by the farmers. This matter then became one of the ways to avoid conflicts in the future. The lack is that the agreement was not written down. Akbar explained that:

"At the contract time, we have discussed the issue of the limit of merchants/buyers to harvest all the yields because sometimes there are incidents; the merchants tend to slack off to harvest the plans when the prices are low because they wait for the prices to increase, while we as the farmers have already wanted to plow the land, but it is constrained because the plants have not been harvested. The lack is that there is no written agreement because we only have mutual trust and responsibility. "38

Concerning the problem described by Akbar, Herliati's statement confirms that:

"Selling the plants with the mappaja' system is fine and profitable indeed; it is just that we as the farmers sometimes have problems when it comes to harvest time. The merchants/traders have not harvested all their plants because prices are, and they are still waiting for prices to increase. So, further land management becomes constrained. Then it is claimed as the lack because sometimes we do not discuss the issue of harvest limits; we only focus on price and plant care. " 39

From the explanation above, it can be seen that everything must be discussed clearly and detailed when the contract/agreement is taken. Then, it has been clarified the importance of taking note of all the activities in mu'amalah, where this process is carried out cashless. As in the payment process, even though it is done twice, the money is already received by the farmer but the merchant will receive the goods later after the harvest.

In another study, the related issue is also explained. It is concern to the rights and obligations of the merchant and buyer, Herliati explains it as the seller:

\footnotetext{
${ }^{37}$ Departemen Agama RI, Al-Quran Dan Terjemahnya..., p. 48

${ }^{38}$ Nur Akbar (27 years old), Farmer, Interview, West Sinjai, January $8^{\text {th }} 2021$

${ }^{39}$ Herliati (47 years old), Farmer/housewife, Interview, West Sinjai, January $6^{\text {th }} 2021$.
} 
'Trading with the mappaja' system is carried out when the plants have not been harvested, so our obligation as sellers is to keep taking care of the plants until the harvest time comes because buyers only harvest the results immediately. Then, we have received the money. Sometimes some merchants keep asking that we as the farmer should harvest by ourselves, and then the merchants give the additional cost as wages, so the merchants need to carry the goods directly."40

Herliati's explanation is clarified by Ali's explanation which states that:

"Regarding the plant care issue, the farmer/merchant is still responsible because we have received the money, and the merchants only have to harvest. Related to the harvest problem in the future, if the merchant asks us as the seller to harvest when the harvest time comes, we will get additional money from the merchants as harvest wages. However, sometimes there is also someone who harvests by himself or orders someone else."41

Aside from the rights and obligations of the farmers as the merchant, there are also rights and obligations of the merchant by giving the money to the farmers under the agreement. If the payment made twice, the merchant obliged to give the unpaid money from the agreed price to the farmer even though a price change causes merchant's losses.

Sumarni explained the rights and obligations as a merchant as follows:

"We, as the buyer can only harvest directly, so the responsibility for the plant, especially the maintenance problem, remains to the merchant. So, for example, the harvest period will come on two or one month after the agreement is made, then during that time, the merchants take care of the plant, and our obligation as the buyer is to give all the remaining money to the merchant after harvesting. But I also often ask the farmers (merchant) to harvest them all in once, and then I will give them the salaries apart from the price of the plants. Regarding the issue of wages or salaries, I calculate it daily. If I conduct it this way, it would be easier for me as a merchant because I only need to pick up the goods; at least I only go to the location to control at the harvest time.",42

There are rights and obligations for clove plant, for merchants/buyers and farmers/sellers; it is almost the same with others that the payment is immediately received when the contract is assigned, and there is also repayment after the harvest is done. The difference is that when they are fruitful, they no longer require special care. Although the plants' condition is not ready to harvest in the transaction, it was different from the vegetables. So for the clove plants, the rights and obligations for the farmers are to receive a certain amount of money according to the agreement and give full rights to the merchants/buyers to take the fruit at the harvest time.

The rights and obligations for the merchants/buyers are to give a certain amount of money according to the agreement, and then they have the right to claim the fruit of the clove. Moreover, the merchants/buyers are also obliged to maintain the condition of

${ }^{40}$ Herliati (47 years old), Farmer/housewife, Interview, West Sinjai, January $6^{\text {th }} 2021$

${ }^{41}$ Ali.C (48 years old), Farmer, Interview, West Sinjai, January $8^{\text {th }} 2021$

${ }^{42}$ Sumarni (40 years old), Merchant, Interview, West Sinjai, January $6^{\text {th }} 2021$. 


\section{Mappaja' Practices in Agricultural Commodity Trading in The District of West Sinjai, Sinjai Regency}

the clove tree so that it would not be damaged during harvesting, such as cutting or pruning part of the tree brancp. As Abdullah said that:

"In the practice of cloves mappaja', the merchants have the full right to harvest after the contract assigned. The condition of the cloves on the transaction is that they are ready to harvest, or one month at the very latest before the harvest comes. There is no special care when the cloves have fruited, unlike the other plants. So after we received the money, everything about the fruit relied on the merchant. It is the merchants/buyers who have to take care and be responsible when the harvest come, because sometimes there are merchants who damage the trees by cutting down some of the branches when at least. While their right is only to take the fruit, and after the harvest is done, the contract ends, and the total ownership return to the farmer." $" 43$ merchant:

An explanation clarifies the explanation from Abdullah from Winda as a

"Concerning the problem of the cloves that I bought with the mappaja' system, it became my full right after the contract was assigned, and I gave the money to the seller. So if the harvest has not come yet, I am the one who often sees the condition of the cloves in the land. If the harvest period has come, then we, as the buyer, are still responsible for the condition of the trees to protect them from damage. Even though some fruits are difficult for us to pick, we still ask the owner's permission to cut some of the branches. After the harvest is done, the rights will automatically return to the farmers because we only buy the fruit. ",44

The explanation above can conclude that the rights and obligations for both parties are:

a) The farmers are obliged to keep taking care of the plants until harvest time.

b) The merchants are obliged to make payments according to the agreement. However, for the plants such as cloves, farmers only are able to receive the money according to the agreement and are obliged to give full rights to the merchant, but the merchants themselves are obliged to pay the farmers and also obligated not to damage the clove trees when they are harvested.

From some of the explanations above, it can be concluded that in the practice of mappaja', everything is agreed when the contract assigned and there must be a written form agreement as the evidence and the witnesses should be provided so that there would be a strong evidence if any problems come in the future, so that neither party would be harmed later. However, when it is viewed from the aspect of the pillars of trading in Islam, the practice of mappaja' has fulfilled three criteria.

From the view of the pillars of trading in Islam, the practice of mappaja' has met the criteria, namely (1) The existence of sellers and buyers are the merchants and farmers, (2) The existence of ijab qabul is described in the practice which the merchants verbally say that they are willing to buy crops from the farmers, and the farmers have

\footnotetext{
${ }^{43}$ Abdullah (59 years old), Farmer, Interview, West Sinjai, January $11^{\text {th }} 2021$.

${ }^{44}$ Winda (27 years old), Merchant, Interview, West Sinjai, January $6{ }^{\text {th }} 2021$.
} 
the right to give their harvests to the merchants according to the agreement, and (3) ma'qud alaih is the good in a contract or good in which its prices are discussed.

\section{CONCLUSION}

The explanation above can conclude that the practice of mappaja' in agricultural commodities has been going on for a long time. The mechanism of mappaja' is by estimating the number of plants based on mutual trust and responsibility. Agricultural commodities used as mappaja' objects are cloves and vegetables (carrots, cabbage, and tomatoes). The payment method in mappaja' practice is carried out in two ways namely full payment and payment is made twice; it is done when the contract assigned as a down payment and a sign of completion and the rest could be paid after harvest. The condition of the plant in the mappaja' transaction is that they are ready to be harvested and not ready for harvest. The rights and obligations of both parties are that the merchants are obliged to make payments to farmers according to the agreement, and for the farmers, they can continue to take good care of the plants when their condition is still not ready for harvest.

\section{REFERENCES}

Abdul Haris, "Perjanjian Jual Beli Duku Dengan System Ijon Antara Pembeli Dengan Masyarakat Di Kecamatan Maro Sebo Kabupaten Muaro Jambi”.

Abdul Kholiq Syafa'at dan Rohmatullah “Analisis Hukum Islam Terhadap Praktik Jual Beli Hasil Pertanian Padi Sistem Tebasan Di Dusun Kelir Desa Bunder Kecamatan Kabat Kabupaten Banyuwangi”.

Azizatul Mahmudah dan Bakhrul Huda, "Praktik Jual Beli Jagung dengan Sistem Tebasan di Desa Triwung Lor Kecamatan Kademangan Kota Probolinggo Perspektif Akad Juzāf', el-Qist: Journal of Islamic Economics and Business 10, no. 2 (2020).

http://www.kbbi.web.id.

Juju Jumena, dkk., "Jual Beli Borongan Bawang Merah di Desa Grinting Menurut Tinjauan Hukum Islam", Al-Mustashfa 2, no. 2 (2017).

Juni Iswanto, "Pelaksanaan Jual Beli Hasil Pertanian Dengan Cara Borongan Ditinjau Dari Fiqih Muamalah Didesa Mancon Kecamatan Wilangan Kabupaten Nganjuk", Jurnal Dinamika Ekonomi Syariah 6, no. 2 (2019).

Maryani, dkk., "Pelaksanaan Jual Beli Ijon Di Desa Segaran Kecamatan Tiris Kabupaten Probolinggo Menurut Madzhab Imam Syafi'I”.

Nazar bakri, Problematika Pelaksanaan Fiqh Islam (Jakarta: PT Raja Grafindo persada, 1994). 


\section{Mappaja' Practices in Agricultural Commodity Trading in The District of West Sinjai, Sinjai Regency}

Nurul Inayah, “Analisis Hukum Islam Terhadap Praktek Jual Beli Buah Melon Dengan Sistem Tebas: Studi Kasus di Desa Buluagung Kecamatan Siliragung Kabupaten Banyuwangi", p 67.

Parmadi, “Tinjauan Hukum Islam Terhadap Praktek Jual-Beli Hasil Pertanian Secara Tebas", Naskah Publikasi (Surakarta: Fak. Agama Islam Universitas Muhammadiyah Surakarta, 2014).

Purbayu Budi Santosa dan Aris Anwaril Muttaqin, "Larangan Jual Beli Gharar: Tela'ah terhadap hadis dariMusnad ahmad bin hanbal”, Equilibrium 3, no. 1 (2015).

Siti Khaizul Mustaqimah, "Praktik Jual Beli Durian Secara Tebasan Dalam Kajian Kitab Fatḥu Al-Qarīb: (Studi Kasus di Desa Mantenan Giyanti Kecamatan Candimulyo Kabupaten Magelang)", Wahana Islamika: Jurnal Studi Keislaman 6, no. 1, 2020.

Syamsuddin A. K Antuli, "Pemahaman Masyarakat Tentang Jual Beli Cengkeh Yang Masih Di Pohon (Ijon) Di Kecamatan Passi Barat Kabupaten Bolaang Mongondow", Journal Economic and Business of Islam 2, No. 1, Juni 2017.

Wardani, Fiqh Ekonomi Syari'ah: Fiqh Muamalah (Jakarta: PT Kencana Perdana Media 2013). 